\title{
特殊紙 特集
}

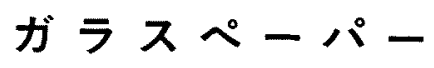

西松 三郎

\section{1. まえがき}

電気材料用にガラス瀻維 $100 \%$ 㕸次元シートが湿式

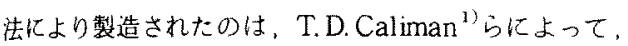
1950 年 9 月, National Bureau of Standards $の$ Test マンンで武抄されたのが最初である゙。五本に执いては， 1950 年代末 230 会社で研觉され始めら机たが ${ }^{3} ， 1960$ 年代の半ば特種製紙によって，電気絶縁板の基材として， 相されたのが最初であるう。

本州製紙は1968 年より，電気材料用ガラスペーパー の開発研究に着手し，1972 年日本で初めてガラスペー パー尃抄マシンを設置した。現在では三菱製紙，日本バ イリーン，オリエンタルアスベスト，広瀬製紙す色々な 形のガラスペーパーを市販されており，この外開発を検 討されている会社は数多くある模椂である。

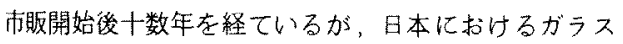
ペーパーの生産は月間約 $80 \mathrm{t}$ と推定され，建材・ルー フィング用加ら始まっだ，欧州上比較すればママシンの台 数も生産量子遥か比少ない。パニック以後の経済情勢加 ら需要の伸びは，はかがかしくないが，建材用に電縁用 にガラスペーパーは，原材料対策，生産性向上に上るコ ストダゥンを達成すれば、日本におけるこれからの商品 の一つであると確信している。

以下，原材料，抄紙，用途別製品について略述する。

\section{2. 原材料}

\section{1 ガラス絩䊒 ${ }^{16)}$}

ガラス織維の製法等については尃門是 ${ }^{4)}$ を参照された い加，その製造法に上り短䋐維(ウール状)上長瀻維に 区別され，䋊維経に上る分類 (表 1)，組成に上る分類 (表て)がある。

いずれの瀻維も若干の前処理を必要とするものも节

\section{Glass Paper}

SABURO NISHIMATSU

Central Research Laboratory, Honshu Paper Co., Ltd., Edogawa-ku, Tokyo, Japan.

本州製紝株式会社中央研究所第 2 研究室長
るが，湿式法により二次元のシートとするてとができる。 現在，特殊用途は別として，最も多量に使用されてい

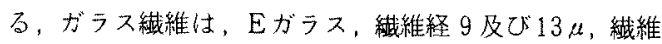
長 6〜12 mm，のチョップドストランドである。

こ扎は量産品種で，価格が安いためであり，欧州では，

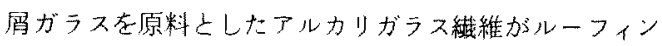
グ用の主流飞とって替っていると言加れ，また $50 \mathrm{~mm}$ のものがTestマシンではあるが試抄されているをうで ある。

しかし，電気材料用がラスペーパーに使用できる向の

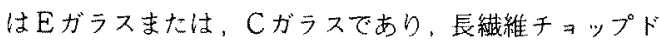
ストランドを用いる場合には，その製造上必要不可欠上 言わ㧈る集束剂を如何に除去するかが，ガラスペーパー 製造上のポイントであり，乙れが不十分であると，得ら 机だガラスペーパーの電気特性，强度を著るしく低下さ せる。

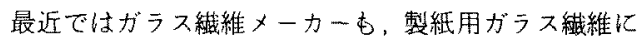
表 1-1 硝子長綎維の直径と呼称 $\left.{ }^{4}\right)$

\begin{tabular}{|c|c|c|}
\hline 呼称名 & 直径呼称 & 值径範囲 $(\mu)$ \\
\hline B & 3 & $3.2 \pm 0.6$ \\
\hline $\mathrm{C}$ & 4 & $4.5 ”$ \\
\hline $\mathrm{D}$ & 5 & $5.7 "$ \\
\hline $\mathrm{DE}$ & 6 & $6.5 "$ \\
\hline $\mathrm{E}$ & 7 & $7.0 "$ \\
\hline $\mathrm{F}$ & 8 & $8.3 ”$ \\
\hline G & 9 & $9.5 "$ \\
\hline $\mathrm{H}$ & 11 & $10.8 "$ \\
\hline $\mathrm{J}$ & 12 & $12.1 "$ \\
\hline $\mathrm{K}$ & 13 & $13.3 "$ \\
\hline L & 15 & $14.6 "$ \\
\hline M & 16 & $15.9 "$ \\
\hline $\mathrm{N}$ & 17 & $17.2 "$ \\
\hline$P$ & 18 & $18.4 "$ \\
\hline
\end{tabular}

表 1-2 微細硝子短瀻維の直径上呼称

\begin{tabular}{|c|c|}
\hline 呼 称 名 & 直径範囲 $(\mu)$ \\
\hline AAAA & $0.2 \sim 0.499$ \\
AAA & $0.5 \sim 0.749$ \\
AA & $0.75 \sim 1.5$ \\
A & $1.6 \sim 2.59$ \\
\hline
\end{tabular}


表 2 硝子辰繊維の成分組成亡性能

\begin{tabular}{|c|c|c|c|c|c|c|c|c|c|c|c|c|c|c|c|c|}
\hline $\begin{array}{l}\text { ガラスの } \\
\text { 種 類 }\end{array}$ & $\mathrm{SiO}_{2}$ & $\mathrm{Al}_{2} \mathrm{O}_{3}$ & $\mathrm{CaO}$ & $\mathrm{MgO}$ & $\mathrm{B}_{2} \mathrm{O}_{3}$ & $\begin{array}{l}\mathrm{Na}_{2} \mathrm{O} \\
\mathrm{K}_{2} \mathrm{O}\end{array}$ & $\mathrm{TiO}_{2}$ & $\mathrm{Li}_{2} \mathrm{O}$ & $\mathrm{ZrO}_{2}$ & $\mathrm{PbO}$ & $\mathrm{BeO}$ & $\mathrm{CeO}$ & $\begin{array}{l}\text { 繊維抗張力 } \\
\mathrm{kg} / \mathrm{mm}^{2}\end{array}$ & $\begin{array}{l}\text { 弾性係数 } \\
\mathrm{kg} / \mathrm{mm}^{2}\end{array}$ & 比重 & 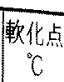 \\
\hline “E”硝子 & 53 & 15 & 21 & 2 & 8 & 0.3 & - & - & - & - & - & - & 350 & 7400 & 2.54 & 0 \\
\hline "C" 硝子 & 65 & 4 & 14 & 3 & 6 & 8 & - & - & - & - & - & - & 28 & 7000 & 2.49 & \\
\hline “A”硝子 & 72 & 0.6 & 10 & 2.5 & - & 14.2 & - & - & - & - & - & - & & - & 2.50 & \\
\hline "L 硝子 & 47.3 & - & - & - & 2.2 & 13.5 & - & - & - & 37.0 & - & - & 170 & 5100 & 4.30 & 18 \\
\hline " $\mathrm{S}$ '硝子 & 64 & 25 & - & 10 & - & 0.3 & - & - & - & - & - & - & 467 & 8700 & 249 & 9 \\
\hline$Y M-31-A$ & 54 & - & 13 & 9 & - & - & 8 & 3 & 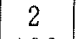 & - & 8 & 3 & 350 & 11200 & 2.89 & - \\
\hline セムフィル & 61.7 & 1.3 & 4 & - & - & 15.4 & - & - & 16.9 & - & - & - & - & - & - & \\
\hline
\end{tabular}

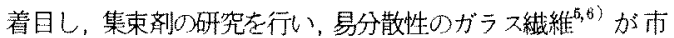
販されている。

しかし，我々製紙メ一カー側からみると，ガラスペー

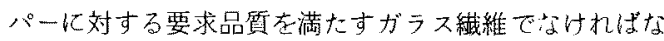
らないのは跑であるが，前述したように，如何に安い ガラス㵶維を入手できるかが，最む重要な課題であり， 今後のガラスペーパーの将来を決定する。

\section{2 ハイイン゙ー}

Calimanらはガラス縺維の表面を前処理によって膠質 化し，ガラス䄉維に自着力を出させた。またある種のガ ラス繊維は紡系後，未乾燥の状態では，若于の自着力を

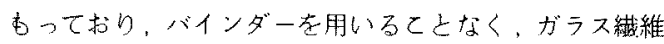
$100 \%$ 二次元シート老製造するととができるが 現在 市貶されている，いわゆる，ガラスペーパーにはバイン ダーが，必要不可欠である。

バインダーの添加方洁には，従来，湿式不織有(化織 緍)に多く用いられて来た，ガラス繊維上一緒に分散さ 甘る内潦法上，乾式不織布に用いられて来た，紙葉形成 後添加する，含浸法とがある。

いずれり場合においても，ガラス紻維の接着性に優れ ているPVAが主体であり，前者の場合、瀻維状PVAバ インダー及び易膨㵎性粉末 PVAバインダーが用いられ る。電気材料用ガラスペーパーの場合，強度だけでなく， 電気特性も併甘て要求され，缕述する場合を除き，ガラ スペーパードけで，ガラスクロス並みの電気特性，特に 㥿沸後の絶縁板の表面抵抗を得るためには，使用できる バインダーは非常に少ない。

我われ製紙メ一カーとしては，バインダ一は水系であ るととが望ましく，ポットライフが長く，乾燥，キュア リングは秒単位であり，しかも，でき上ったガラスペー パーには，次工程に耐えるだけの，耐溶㓣，耐熱強度が 要求され且つ電気特性む要求されるからである。

筆者らは，これらの諸要求をはぼ满足させるガラスぺ ーパーの完成に 3 年近い年月要し，Bブランドとして 市贩している。

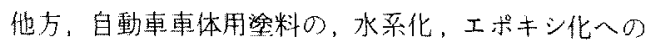
要請に上るもの上思犼る，エポキシ化学の水系化人の
急速な進歩によって伍格，ポットライフ等，若干の問題 点は残しながらも，ガラスパーパー用のバインダーとし て，工ポキシ樹脂が用いられるようにおっだ。

ガラスクロスの䭪合上同じく，電材用ガラスペーパー においても，シランカップリング剂老用途条件に合せて 選択しなけ机ばならない。

\section{3. 抄紙}

\section{1 前処理}

前述したように，紙力に影響の少ない，易分散のガう 不繊維も市販されるようになり，我われ製紙メーカーと しては，报い易くなったが，ガラス繊維の製造時化使网 されている，集束剂中の滑剂(油剤，活性剂)の種類上 付着量がガラス繊維の纷散，紙力に著しい影響をもって 吉り，ガラスペーパーの用途に応し，ガラ又緎維の巽却 及じ前処理条件を決如必要がある。

しかし，通常の製紙に怙ける調成工程と比較すれば， 遥加簡単な工程である。

\section{2 シートフォーメーション}

ガラスペーパー製造上の次の問題点は，ガラス蟣維存 如何に均一に分散さ甘るかということであり，以下5項 目について述心る。

\section{1) ガラス織維の径と長さ}

AA夕ラス，1 1 以下のガラス織維は，パルプと全く

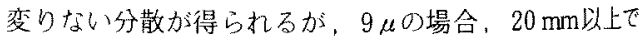
は結束瀻維状のものが発生し易く，地合がとり難くなる が，繊維長上紙力には弶度の相関関係があり，できる限 り長いもの使用することが望ましい。

\section{口) 分散濃度}

通常製紙の場合のインレット濃度の1/10１/200濃 度，すなわち，約 $0.02 \%$ 以下に稀瀵しなければ良好な地 合は得られない。

\section{八）分散液 $\mathbf{p H}$}

Caliman らはpH 3 以下という非常に苛酷な条件であ り設備的に李難しかったのであるが，鼠近では文载 香見られる如く分散剂の使用に上り分散可能な $\mathrm{pH}$ 範进 も広くなり酸性サイドであればよい上うになった。 


\section{二）分散剂}

徒来方ら化䋐紙の製造に用いら扎て来た分散剂を用い ることができるか，その種類，量，添加万法については， ガラスペーパーに合せる必要がある。

\section{木）機械的分散法}

ガラス㵶維の比重は2.5と重いため，沈降し易くまた フロックを作り舄い。このととを念頭において設備の設 計をしな机ばならい。擋拌力か弱く、流動の力向が

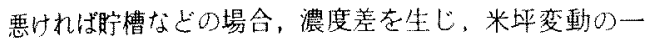
因となる。

従来加ら，化緁紙用いられて来た，各種のホーマー でガラス織維を用い二次元のシート在作ることは可能で ある。しかし，丸絧形式，短網ポンド形式にはるれぞれ一 屒一短があり，いずれを操るべきか難しい問題であるが， ガラス䋘維は判面であり，加表面が滑らかであるため， ワイヤ抜けが非常に多い。すなわちインレット濃度に比 し, 白水中のガラス䋐維濃度が高いこ上走念頭に置き， いず狆のーマーが，スタートアップの時間(無抄時間) が短く，加長時間連続運転が可能であるかによって。 決めるべきである。句論， 巾万向の米坪のバラッキと共

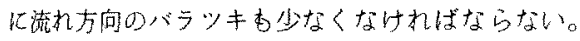

\section{3 乾 燥}

ガラスベーパーの製造にあたり，最も重要な点は，乾 燥であると言っても過言ではない。それは使用するバイ ンダーに上る乾爟表面の活れに対し，如何に表面を再生 するかが製品の品霓，生座性在決めるからである。

化䄉紙，乾式不織布に用いられて来た乾燥方式加用い られており，次の三通りに大別される。

\section{1) ヤンキートライヤー方式}

化縺紙保用いられて来た一般的な万式で，比較的，乾 懆表面の再生も突易であり，侲れた表面性老持つ紙葉を 作ることがでさるしかし，がラスペーパーは，淎に湿 絋箱乾燥するだけでは不十分な場合加多く，キュアリ ングを必要とする。このととはスピードアップによる生 産性向上に対しては，ドライヤーの太径化，高王化が必 要であり，設備投資が過大になる嚾点がある。

\section{ロ）エントレス，メッシュワイヤー：熱風貫通方式}

乾式不織布製造に用いられて来た方式で，熱回収装犆 を設置しない之，熱原単位が高くなるが，熱風貫通方式 はガラスペーパーの㻋な構造から考えて效率のよいあの であり，また熱風温度は比較的容易に高くとれ，段階的 乾燥李可能であり，設備投資む少なくてすむ利点がある。 しかし，最大の難点は，ワイヤーメッシュ表面の再生 であり，各社，それぞれ，ノウハウを持ち操業している。

\section{ハ）メッシュドラム，熱風貫通方式}

文献，力夕ログでは，一番多く出て来万乾燥方式であ
るが，品）場合上りも、ワイヤ一表面の再生が困難で ある。ドライヤ一前半での紙送りに古闍题力゙ある。

\section{4 作業環䞇等}

アスベストと異なり，ガラス瀻維は鲯害てあるとの文

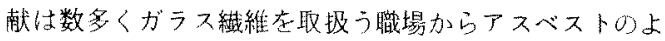
うな職莱病が発生したよいうことはないようでする。

しかしながら，できる限り，ガラス繊維の浮遊算を少 なくするに越したこよはなく，随所に集歴設備をつける こしが好ましい。

ガラス䋐維による皮㵋障害には，個人差があり，本質 的に全く受けつけない人は2〜3\%と言和てて招り，残 りの人達は慣れることにより，苦通感はなくなるといっ

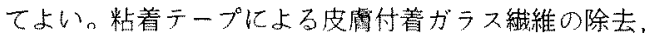
作業終了時の入浴の励行，口ッ力一の整備等の諸対策在 適宜とる必要加ある。

\section{4. 電気材料用カラスペーパー ${ }^{13 \sim 15 \text { ? }}$}

ガラスペーパーを用い 銅張積層板を日本で初めて上 市したのは，現在のニッカン工業である。

一ッカン工業が取得した奏用新案 ${ }^{10}$ 仙图1亿示す構造 のあのであり，当時のガラスペーパーのバインダーに起 因吉る電気特性上の欠陷及びガラ又繊維が短いために発 生士ると思われる，ガラスペーパー積層板の欠陷を，実 に見事に克服したユニークな特許である。しかし，発明 者目身述懷しておられたが，ての特許の存在に上って電 気材料用ガラスペーパーの生産が伸びなかったと言えな いこともない。钼在，䉓材用に生産されているガラスペ 一パーは10t未渵と推定されるが，今後，ガラスクロ 又積層板では得られないパソチング特性を有するガラス ペーパー皘層板が，どこまで伸びるかについては，ガラ スペーパー価格の低減と其に，サンドイッ構造の利点 を生加した，積層板のコストダウンに加っている。

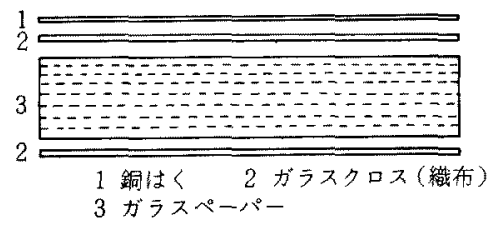

図1サンドイッチタイプ銅張皘層板棬成 ${ }^{10}$

ガラスクロスとの生産速度の比較から，低価格ガラス ペーパーの完成が要望されて久しいが，まだまだ，高価 格である要因の一つは，ガラスペーパー中にある，千リ， 異物に対する納入規格が笽しいととである。

この于リ，異物は抄紙用具の污れ，乾燥表面の污れに よって発生することが多い。前項で述べた乾燥表面再生 
表 3 電気材料用ガラスペーパー紙質

\begin{tabular}{|c|c|c|c|c|c|c|c|}
\hline \multirow[t]{2}{*}{ 銘 } & \multirow{2}{*}{$\begin{array}{l}\text { 米坪 } \\
\left(\mathrm{g} / \mathrm{m}^{2}\right)\end{array}$} & \multirow{2}{*}{$\begin{array}{l}\text { 厚. } \\
(\mu)\end{array}$} & \multirow{2}{*}{$\begin{array}{c}\text { 密 度 } \\
\left(\mathrm{g} / \mathrm{cm}^{3}\right)\end{array}$} & \multicolumn{2}{|c|}{$\begin{array}{c}\text { 引張り強さ } \\
(\mathrm{kg} / 15 \mathrm{~mm})\end{array}$} & \multirow[t]{2}{*}{ 備 } & \multirow[t]{2}{*}{ 惹 } \\
\hline & & & & $T$ & $Y$ & & \\
\hline $\mathrm{GMC}-00-100(\mathrm{~B})$ & 100 & 800 & 0.12 & 4.6 & 3.2 & 本 州 製 紙 & 酎者沸性品 \\
\hline $\mathrm{GMC}-00-080(\mathrm{~B})$ & 80 & 480 & 0.17 & 4.1 & 3.4 & "r & \\
\hline GMC $-00-060(\mathrm{~B})$ & 60 & 350 & 0.17 & 3.6 & 2.8 & " & \\
\hline $\mathrm{GMC}-00-050(\mathrm{P})$ & 50 & 280 & 0.18 & 2.5 & 2.2 & $"$ & サンドイッチタイプ用 \\
\hline $\mathrm{GMC}-00-033(\mathrm{P})$ & 33 & 190 & 0.18 & 1.8 & 1.6 & $"$ & " \\
\hline 4050 & 50 & 300 & 0.17 & 4.8 & 2.1 & 日本バイリーン & \\
\hline 6050 & 50 & 300 & 0.17 & 5.8 & 2.7 & " & 耐熱器 \\
\hline
\end{tabular}

の重要性はこのためである。

現在ガラスペーパーを使用し，サンドイッチ構造の精 層板を市販しているメーカーは前述のニッカン工業のは 加，三蔆瓦斯化学，新神戸電気があり，ガラスペーパー 100\%の皘層板は利昌工業，日立化成より市販されてい 万。

表 3 に電材用ガラスペーパーの紙質データーを記載し to

\section{5. 建材用ガラスペーパー}

5.1 ルーフィング用カ门ラスペーパー

ガラスペーパーを基材としたルーフィング材は，従来 の故紙を原料とした紙基材のものに比べ，単価は高いけ れども耐久性，耐候性，而腐朽性が高いことから，日本 において古ここ10 年位前加ら使用され始力た。

まだまだ，欧州程の普及度ではないにしても，ガラス ペーパーを基材とするルーフィング材は合成織維不織布 を基材とするルーフィング材との併用により，日本の気 候に合せた形で着実に普及し，伸びてきている。1977 年には，穴あきアスファルトルーフィングとしてJIS制 定がなされだ”。の穴あきルーフィングは図 2 に示す 上うに， $28 \mathrm{~mm} \phi$ 穴を $1 \mathrm{~m}^{2}$ 当り156ケあけたあので， 部分接着工法用のルーフィング材として用いられるもの である。

との部分接着工法は，従来の密着工法に比べ，下地の ひび割れや，ジョイント部の動きにより受ける局部応力 を髣和し，洩水の原因よなるルーフィング材の破盺を起

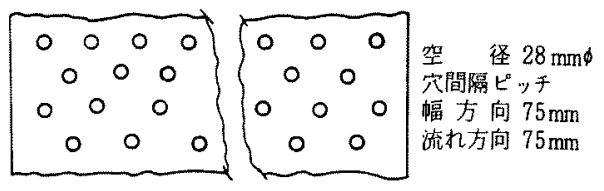

1 紙 幅 $1000 \mathrm{~mm} \longrightarrow$

図 2-1穴あきルーフィング用 ガラスペーパー寸法

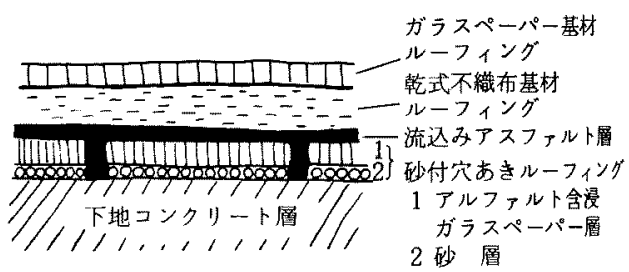

冈2-2穴あきルーフィング部 分接着工法䉼面の一例

こさないこと及び下地の水分が日射により気化膨張した 時，ふくれ現象を起こさない，二つの利点を持ってい b。

このは加にも，命工法用，壁用等，見在ではルーフ ヘング用しして 700 t 程度のガラスペーパーが使用され ているに過ぎないが、ガラスペーパーのコストダウン を計れば，普及度の伸びむ著しく大きい市場となるこ とが期待される。

表 4 にルーフィング用ガラスペーパーの紙質データー

表 4 ルーフィング用ガラスペーパー紙質

\begin{tabular}{|c|c|c|c|c|c|c|}
\hline \multirow[t]{2}{*}{ 銘 } & \multirow{2}{*}{$\begin{array}{l}\text { 米 坪 } \\
\left(\mathrm{g} / \mathrm{m}^{2}\right)\end{array}$} & \multirow{2}{*}{$\begin{array}{c}\text { 厚 d } \\
(\mu)\end{array}$} & \multirow{2}{*}{$\begin{array}{c}\text { 密 度 } \\
\left(\mathrm{g} / \mathrm{cm}^{3}\right)\end{array}$} & \multicolumn{2}{|c|}{$\begin{array}{c}\text { 引張り強さ } \\
(\mathrm{kg} / 15 \mathrm{~mm})\end{array}$} & \multirow[t]{2}{*}{ 備 } \\
\hline & & & & $T$ & $Y$ & \\
\hline $\begin{array}{l}\text { グラスパー50 } \\
\text { グラスパー60 }\end{array}$ & $\begin{array}{l}50 \\
60 \\
\end{array}$ & $\begin{array}{l}300 \\
350\end{array}$ & $\begin{array}{l}0.17 \\
0.17\end{array}$ & $\begin{array}{l}5.8 \\
7.4\end{array}$ & $\begin{array}{l}4.6 \\
6.0\end{array}$ & 本州製紙 \\
\hline $\begin{array}{l}\text { HYTOL N } 18 \\
\text { HYTOL S } 30\end{array}$ & $\begin{array}{l}50 \\
65 \\
\end{array}$ & & & $\begin{array}{l}3.6 \\
6.0\end{array}$ & 2.4 & Van Gelder Papier (Holland) \\
\hline B 50 & 50 & & & 3.0 & 2.0 & Ahlstrom (Finland) \\
\hline
\end{tabular}


夻咭载した。

5.2クッションフロア一用

カラスペーパー

ここ数年来，生長度り著しい建 材の一つが，従来のプラスチック タイルに代りつつある，長尺物の クッションフロアー材と呼ばれる

床材である。プラスチッタタイルに比へ，施工費のコ ストダウンとなり，発泡層を持っているため，齿行感が 政哣された。

現時点では，てれらクッションフロアーの大部分はア スベストペーパーをバッキング材しして使用しているす のであるが，このアスベストペーパーをガラスペーパー に置き換えようという試みがすべてのフロアー材製造メ 一カーでなされて抢り，一部のメ一カーでは睌に机販さ れている。欧州のあるガラスパーパーメーカーでは，ル 一フィング用の3㥉近い生應量在出しているとも言われ b。

パルプを混抄し，目止めをしたものが，一時、室内用 のバッキング材しして，用いられたことあ古ったが，ガ ラスペーパーは密度加低く，ポーラスであるため，年の ままアアスべストの代替として，バッキングに用いると とができない。晛在は，中間層（図3参照）または表通 層に用いられ，日本家屋に合せた合板に貼り会せたすの 6検討されている。このため，ガラスペーパーに対して， 酎熱独度寸法安定性の要求之其に，表面の平滑性が春に 跾しく要求される(表 5 参照)。しれは，ガフスペーパ 一のシワ，四凸がそのまま床材表面に再現されるからで ある。

今後の日本に扣りる。建筑様式，生活様式の変化は， ファッション性に富み，歩行感屯良く施工費の安い， クッションフロアー材の普及に更化拍車をかけるであるう。 床栍用ガラスペーパーは漸く緒についたばかりである。

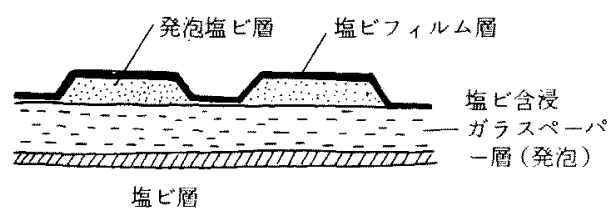

図3クッションフロア一構成一例 (ガラスペーパー使用)
表 5 床忉用ガラスペーパー紙毁

\begin{tabular}{|c|c|c|c|c|c|c|}
\hline \multirow{2}{*}{$\begin{array}{l}\text { 长 坪 } \\
\mathrm{g} / \mathrm{m}^{2}\end{array}$} & \multirow{2}{*}{$\begin{array}{l}\text { 厚 } \\
(\mu)\end{array}$} & \multirow{2}{*}{$\begin{array}{c}\text { 密 度 } \\
\left(\mathrm{g} / \mathrm{cm}^{3}\right)\end{array}$} & \multicolumn{2}{|c|}{$\begin{array}{c}\text { 引张り䖝度 } \\
(\mathrm{kg} / 15 \mathrm{~mm})\end{array}$} & \multirow[t]{2}{*}{ 犕 } & \\
\hline & & & $T$ & $Y$ & & \\
\hline 50 & 310 & 0.16 & 48 & 3.1 & 本州製紙 & \\
\hline 75 & 460 & 0.16 & 7.0 & 6.6 & " & \\
\hline 35 & 175 & 0.20 & 3.3 & 2.2 & " & 全板用 \\
\hline
\end{tabular}

\section{6.むすび}

本稿に报いては，ガラスペーパーについて電材用，建 材用にしはりり記述したがしのほかにも原材料としては ロックウール，女ラミックファイバーなじばすバての無 機縅維を使用することが可能であり，また各種有機合成

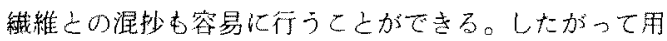
途屯前述のもの以外，フィルタ一，断就材，FRP等々 多岐にわたっている。いずれにしてす，我われ製紙メ一 カーによって、これからの节場であるこしに間違いはな い上思われる。そしてその泫場の大きさを㶧定するもの は，再三にわたり述心゙が，安い原料の確保，生産性、 歩留向上に上るコストダウンであると思う。

\section{文献}

1) T. D. Caliman, Electrical Properties of Glass Fiber Paper, Part I (May 1951), Part II (Oct. 1952), Naval Research Lab. Report

2) S. W. Schulmeyer, Tappi, 39, 217A (Sept. 1956)

3）安倍川工業，特公昭 36-9601

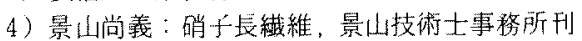

5) 旭ファ1バーガラス，特公開昭 52-132104

6) 富士ファイバーガラス、実公開昭 53-137210

7) オーエンス・ユーニング・ファイバーガラス・コー ポレーション，特公昭 45-5078

8) 日本バイリーン＼cjkstart特公昭 52-796

9) 日本バリーン, 特公昭 52-39474

10）日東製缶 (ニッカン工業)，実公昭 43-32228

11) あなあきアスファルトルーフィングJIS A 6023

12) N. B. Scheffel, Tappi, 58, 56 (May 1975)

13) A. W. Brown, SPE Journal, 1259 (Oct. 1962)

14) C. F. Dancelmajer, IEEE 32C1-17

15) J. R. Benzinger, Tappi, 49, 460 (Oct. 1966)

16) C. W. Charon, Pulp \& Paper, 84 (Oct. 1971)

(昭和 54 年 2 月 24 日受理) 